\title{
Novel hexacoordinate organosilicon(IV) complexes of diethylenetriamine Schiff base with $\mathrm{SiO}_{2} \mathrm{~N}_{3}$ skeleton
}

\author{
Jugal K. Puri,* Raghubir Singh, Varinder K. Chahal, and Raj P. Sharma \\ Centre of advanced Studies and Department of Chemistry, Panjab University, Sec 14, \\ Chandigarh - 160 014, India \\ E-mail:profjkpuri@yahoo.com
}

\begin{abstract}
Some novel hexacoordinate silicon(IV) complexes with a $\mathrm{SiO}_{2} \mathrm{~N}_{3}$ skeleton were synthesized by using potentially pentadentate ligand $N, N^{\prime}$-diethylenetriamine-bis(salicylideneimine). The aforesaid ligand, obtained by the condensation of diethylenetriamine and salicylaldehyde, contains two $\mathrm{N}$ of azomethine $\mathrm{C}=\mathrm{N}$ group, two $\mathrm{O}$ of phenolic $-\mathrm{OH}$ group and one $\mathrm{N}$ of $-\mathrm{NH}-$ group capable of coordination. The ligand reacts with $\mathrm{RSiCl}_{3}\left(\mathrm{R}=\mathrm{CH}_{3}, \mathrm{C}_{6} \mathrm{H}_{5}, \mathrm{C}_{2} \mathrm{H}_{5}, \mathrm{CH}=\mathrm{CH}_{2}\right)$ in the presence of triethylamine to yield hexacoordinate silicon complexes 1-4. The resulting complexes were characterized by IR spectroscopy, ${ }^{1} \mathrm{H},{ }^{13} \mathrm{C},{ }^{29} \mathrm{Si} \mathrm{NMR}$ spectroscopy and elemental analysis. The geometry and hexacoordination was confirmed by comparing the experimental results with computational studies by using GAUSSIAN 03 series of programs. The IR frequencies and ${ }^{29} \mathrm{Si}$ NMR shifts calculated for isomer B with Density Functional Theory (B3LYP-3-21+G* basis set) correlate with experimental values and suggested the geometry of synthesized complexes. Total energies, dipole moment and bond lengths were calculated from the geometries optimized with semi-empirical methods.
\end{abstract}

Keywords: $N, N^{\prime}$-Diethylenetriamine-bis(salicylideneimine), Schiff base, hypercoordinate silicon complex, Density Functional Theory 


\section{Introduction}

Coordination chemistry of Schiff base ligands has been a fascinating area of current research interest to the inorganic chemists all over the world. Schiff bases bearing additional donor groups represent the most important class of heteropolydentate ligands capable of forming mono, bi and polynuclear complexes with different metal ions. Recently, Asmy and his co-workers ${ }^{1}$ reported the synthesis and characterization of $\mathrm{Mn}(\mathrm{II}), \mathrm{Co}(\mathrm{II})$ and $\mathrm{Ni}(\mathrm{II})$ complexes using $N, N^{\prime}-$ diethylenetriamine-bis(salicylideneimine) as ligand. Previously, Benabdallah and his coworkers ${ }^{2}$ studied the behavior of $\mathrm{Cu}(\mathrm{II})$ complex of the same Schiff base spectrophotometerically.

The chemistry of complexes with hypercoordinate silicon atoms is interesting from many points of view such as reactivity, biological activity and structural features as reported in several reviews $^{3-5}$. Wagler and co-workers ${ }^{6-10}$ synthesized a large number of hypercoordinated complexes of silicon by using different salen and salphen type ligands and studied their reactivity. Recently, Bohme and his co-workers ${ }^{11}$ also reported a new application of Wagler elimination by synthesizing a macrocyclic silicon enamine derivative. Some silicon complexes with Schiff bases also possess biological activity. Singh et. al. ${ }^{12-14}$ recently, reported the activity of Schiff base complexes with silicon against the pathogenic fungi and bacteria. The insecticidal and nematicidal activities were also reported for some hypercoordinate silicon complexes with sulphonamide imine ${ }^{15}$ as ligand. Therefore, the reported work may be of interest for some researchers.

In continuation with our previous studies on hypercoordinate silicon compounds ${ }^{16-18}$, we aimed at the synthesis and characterization of novel neutral hexacoordinate silicon(IV) complexes with pentadentate ligand, $N, N^{\prime}$-diethylenetriamine-bis(salicylideneimine) derived from salicylaldehyde and diethylenetriamine (Scheme 1). The resulting compounds contain $\mathrm{SiO}_{2} \mathrm{~N}_{3}$ skeleton. Thus, pentadentate chelating ligand proved to be suitable for complexation with different silanes leading to hexacoordinate silicon complexes which are suggested by quantum mechanical studies such as Density Functional Theory and semi-empirical methods. The geometries were optimized by semi-empirical methods to calculate their total energies, bond lengths and dipole moment.
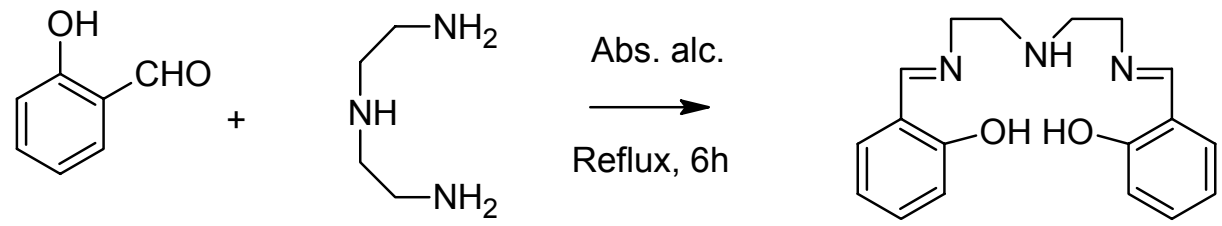

\section{Scheme 1}




\section{Results and Discussion}

The reaction of $N, N^{\prime}$-diethylenetriamine-bis(salicylideneimine) (L) with methyltrichlorosilane, phenyltrichlorosilane, ethyltrichlorosilane and vinyltrichlorosilane in 1:1 molar ratio in THF yielded 1, 2, 3 and 4 complexes, respectively (Scheme 2). The complexes were characterized by using IR, ${ }^{1} \mathrm{H},{ }^{13} \mathrm{C}$ and ${ }^{29} \mathrm{Si}$ NMR spectra. The reaction proceeded smoothly with precipitation of $\left(\mathrm{CH}_{3} \mathrm{CH}_{2}\right)_{3} \mathrm{~N}$.HCl. In the resulting complexes, HO-N-NH-N-OH was the donor system of ligand molecule. The complexes were found to be monomeric as evidenced by their $\mathrm{C} \mathrm{H} \mathrm{N}$ analysis.

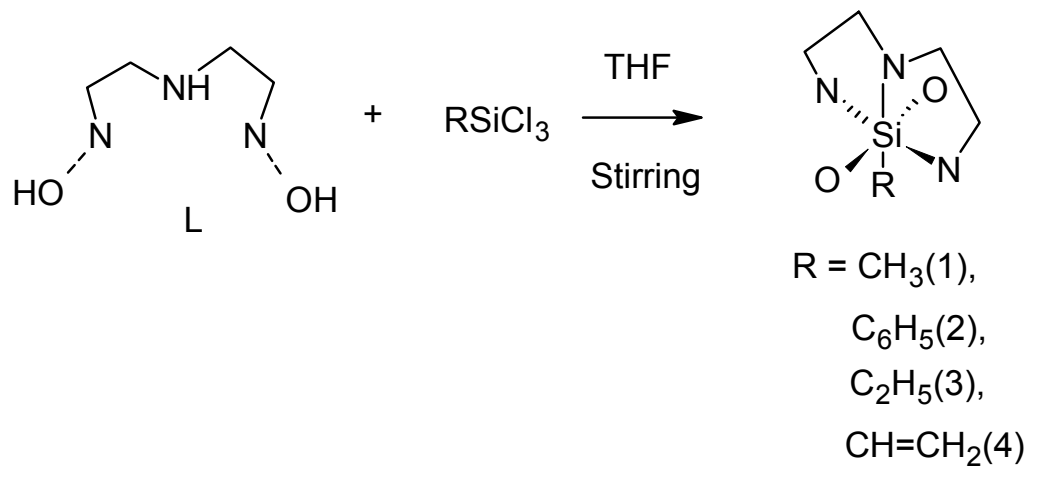

\section{Scheme 2}

The mode of bonding in these hypercoordinate complexes has been proposed on the basis of IR and NMR spectral evidences which were also supported by the work reported in literature on donor system of this ligand ${ }^{1}$. The crystals suitable for X-ray analysis were not obtained, therefore, the NMR and IR data observed for synthesized complexes was compared with the results of quantum mechanical calculations. The prepared complexes can exist in four possible conformational isomers (Figure 1) which were optimized with semi-empirical studies to obtain their relative energies. 


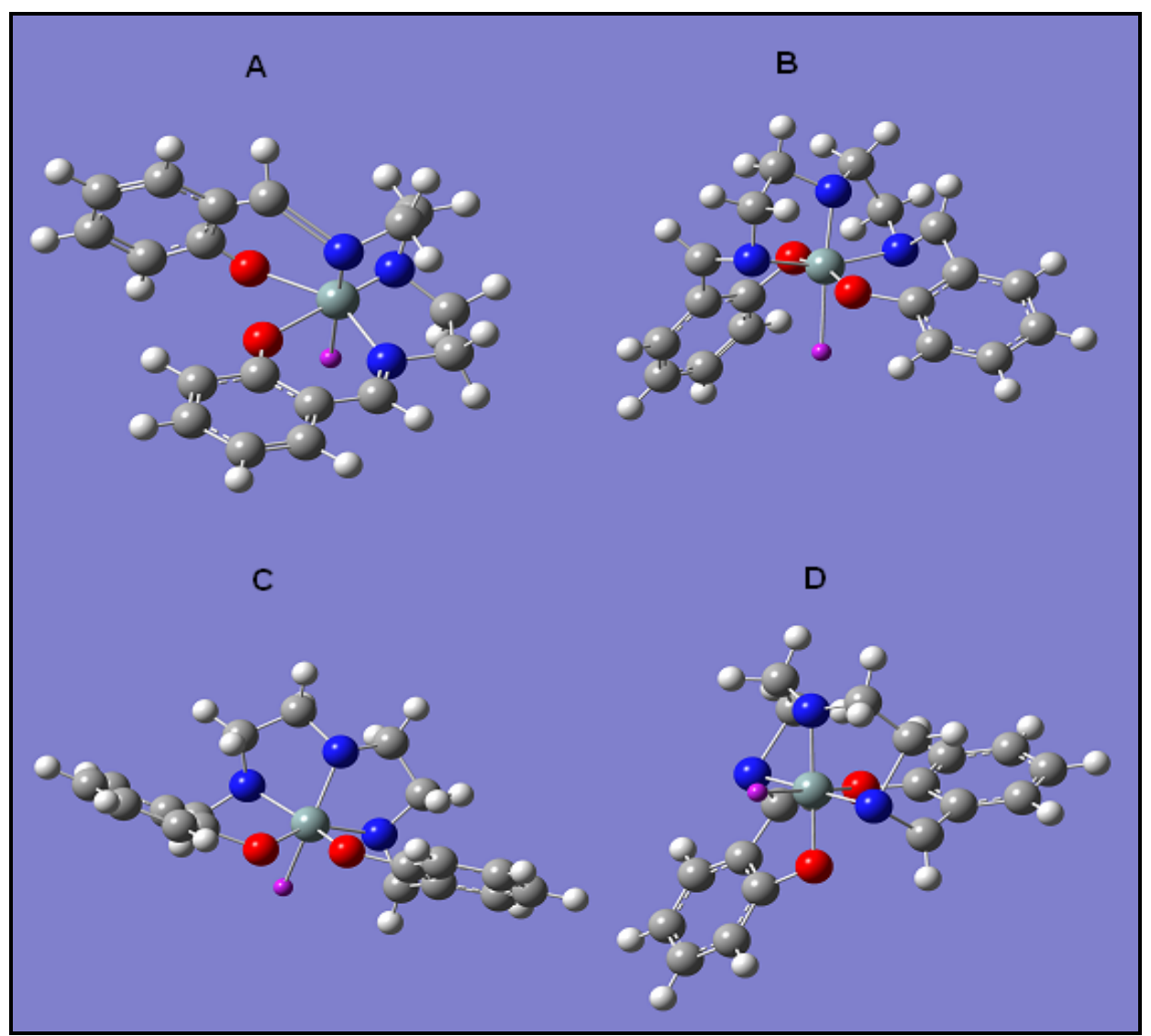

Figure 1. Four possible isomers (A-D) for synthesized complexes.

\section{Theoretical studies}

The limited literature on computational studies of hypercoordinated silicon is due to large size of these molecules which restricts these studies to semi empirical methods ${ }^{19-21}$. The IR frequencies were obtained by using structures optimized with PM3 methods and ${ }^{29} \mathrm{Si}$ NMR shifts were calclulated by Density Functional Theory calculations performed at $3-21+\mathrm{G}^{*}$ basis set and the results were compared with experimental data. IR data computed with PM3 for isomer B showed close proximity to the experimental values but significant changes were observed for other isomers $\mathrm{A}, \mathrm{C}$ and $\mathrm{D}$. This may be attributed to the different bonding modes observed in these isomers after optimization. Isomers $\mathrm{A}$ and $\mathrm{B}$ showed hexacoordination in the complexes whereas isomers $\mathrm{C}$ and $\mathrm{D}$ were observed as tetra and penta coordinated, respectively on the basis of PM3 studies. To confirm the coordination in complexes, ${ }^{29} \mathrm{Si} \mathrm{NMR}$ was recorded and compared with theoretical values which confirmed the hexacoordination in these complexes. From both studies, structure of complexes was suggested same as in isomer B. The four complexes, 1-4 were then optimized with other semiempirical methods such as AM1, PM3MM and MNDO to calculate the bond lengths, total energies and dipole moment (Table 1). The optimized geometries of prepared complexes 1-4 with PM3 method are shown in Figure 2. 


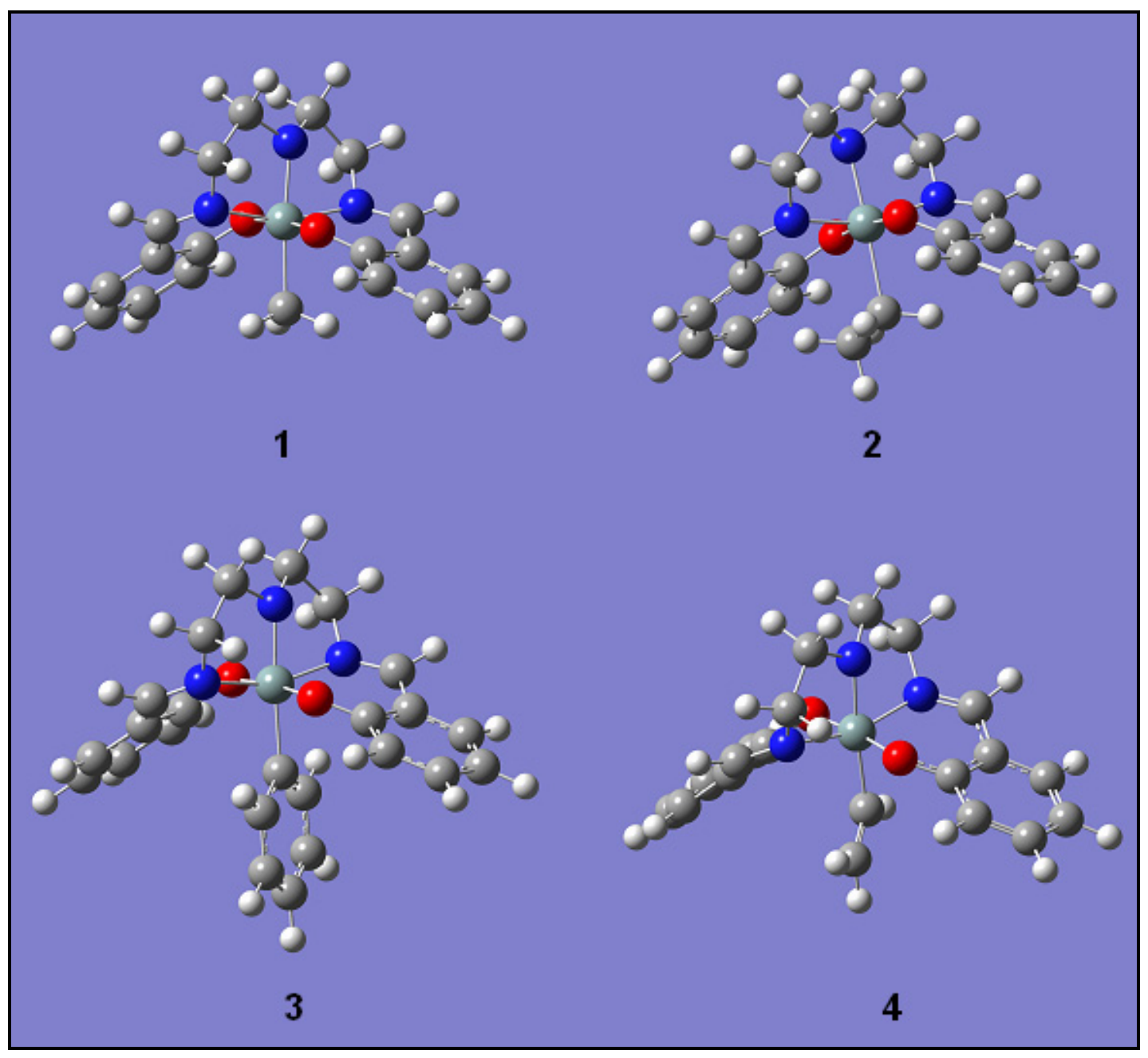

Figure 2. Optimized geometries for complexes 1-4.

\section{IR spectra}

IR spectrum of the ligand exhibits a strong band due to $v(\mathrm{C}=\mathrm{N})$ at $1631 \mathrm{~cm}^{-1}$ and broad band at $3150-3415 \mathrm{~cm}^{-1}$ due to $v(\mathrm{O}-\mathrm{H})$ and $v(\mathrm{~N}-\mathrm{H})$ which is consistent with the literature. ${ }^{2}$ Peaks due to $v\left(\mathrm{NH}_{2}\right)$ and $v(\mathrm{C}=\mathrm{O})$ characteristic of reactants were not observed in the spectrum of ligand.

The assignment of peaks in IR spectra of complexes showed the absence of O-H and $\mathrm{N}-\mathrm{H}$ bands which indicated the involvement of $\mathrm{OH}$ and $\mathrm{NH}$ groups in coordination after the deprotonation of functional groups. The band at $1631 \mathrm{~cm}^{-1}$ shifted to lower frequency side, showing coordination through the azomethine nitrogen. New bands due to $v(\mathrm{Si} \leftarrow \mathrm{N})$ and $v(\mathrm{Si}-\mathrm{O})$ modes were observed which further support the coordination through azomethine nitrogen, phenolic oxygen and $\mathrm{N}$ of $-\mathrm{NH}$ - with silicon atom. IR data calculated for four possible isomers showed a variation in peaks of $\mathrm{Si}-\mathrm{O}, \mathrm{Si} \leftarrow \mathrm{N}$ and $\mathrm{C}=\mathrm{N}$ bond frequencies depending upon the coordination behavior. The values obtained from experimental analysis correlate well with values computed from PM3 method for the isomer B suggesting hexacoordination in these complexes (Table 2). 
Table 1. Semi-empirical studies of 1-4

\begin{tabular}{|c|c|c|c|c|}
\hline Parameters & AM1 & PM3 & PM3MM & MNDO \\
\hline \multicolumn{5}{|c|}{ Compound 1} \\
\hline Total energy (a.u.) & -0.0358 & -0.0754 & -0.0754 & -0.0774 \\
\hline Dipole moment & 2.6 & 2.0 & 2.0 & 0.84 \\
\hline $\mathrm{Si}-\mathrm{N}(1)$ & 1.72 & 1.86 & 1.86 & 1.82 \\
\hline $\mathrm{Si}-\mathrm{N}(2)$ & 1.82 & 1.95 & 1.93 & 1.99 \\
\hline $\mathrm{Si}-\mathrm{N}(3)$ & 2.67 & 1.93 & 1.94 & 1.99 \\
\hline $\mathrm{Si}-\mathrm{O}(4)$ & 1.85 & 1.81 & 1.80 & 1.82 \\
\hline $\mathrm{Si}-\mathrm{O}(5)$ & 2.56 & 1.80 & 1.81 & 1.83 \\
\hline $\mathrm{Si}-\mathrm{C}$ & 1.78 & 2.04 & 2.04 & 1.90 \\
\hline \multicolumn{5}{|c|}{ Compound 2} \\
\hline Total energy (a.u.) & 0.0204 & -0.0193 & -0.0193 & -0.0343 \\
\hline Dipole moment & 2.3 & 3.1 & 3.1 & 1.1 \\
\hline $\mathrm{Si}-\mathrm{N}(1)$ & 1.72 & 1.86 & 1.86 & 1.83 \\
\hline $\mathrm{Si}-\mathrm{N}(2)$ & 1.82 & 1.93 & 1.93 & 2.00 \\
\hline $\mathrm{Si}-\mathrm{N}(3)$ & 2.67 & 1.94 & 1.94 & 2.00 \\
\hline $\mathrm{Si}-\mathrm{O}(4)$ & 1.85 & 1.80 & 1.80 & 1.82 \\
\hline $\mathrm{Si}-\mathrm{O}(5)$ & 2.57 & 1.80 & 1.80 & 1.82 \\
\hline $\mathrm{Si}-\mathrm{C}$ & 1.75 & 2.04 & 2.04 & 1.89 \\
\hline \multicolumn{5}{|c|}{ Compound 3} \\
\hline Total energy (a.u.) & -0.0405 & -0.0781 & -0.0817 & -0.0817 \\
\hline Dipole moment & 2.5 & 2.2 & 2.2 & 2.2 \\
\hline $\mathrm{Si}-\mathrm{N}(1)$ & 1.72 & 1.86 & 1.86 & 1.86 \\
\hline $\mathrm{Si}-\mathrm{N}(2)$ & 1.83 & 1.95 & 1.93 & 1.94 \\
\hline $\mathrm{Si}-\mathrm{N}(3)$ & 2.74 & 1.93 & 1.94 & 1.93 \\
\hline $\mathrm{Si}-\mathrm{O}(4)$ & 1.85 & 1.81 & 1.80 & 1.79 \\
\hline $\mathrm{Si}-\mathrm{O}(5)$ & 2.53 & 1.80 & 1.81 & 1.80 \\
\hline $\mathrm{Si}-\mathrm{C}$ & 1.80 & 2.10 & 2.10 & 2.10 \\
\hline \multicolumn{5}{|c|}{ Compound 4} \\
\hline Total energy (a.u.) & 0.0041 & -0.0334 & -0.0336 & -0.0510 \\
\hline Dipole moment & 3.00 & 2.4 & 2.4 & 0.73 \\
\hline $\mathrm{Si}-\mathrm{N}(1)$ & 1.72 & 1.86 & 1.86 & 1.82 \\
\hline $\mathrm{Si}-\mathrm{N}(2)$ & 1.82 & 1.93 & 1.93 & 1.99 \\
\hline $\mathrm{Si}-\mathrm{N}(3)$ & 2.71 & 1.94 & 1.94 & 1.99 \\
\hline $\mathrm{Si}-\mathrm{O}(4)$ & 1.84 & 1.81 & 1.80 & 1.82 \\
\hline $\mathrm{Si}-\mathrm{O}(5)$ & 2.59 & 1.80 & 1.81 & 1.83 \\
\hline $\mathrm{Si}-\mathrm{C}$ & 1.74 & 2.00 & 2.38 & 1.86 \\
\hline
\end{tabular}


Table 2. Characteristic IR bands $\left(\mathrm{cm}^{-1}, \mathrm{KBr}\right.$ plates) of isomers (A-D) calculated by theoretical studies and experimental data

\begin{tabular}{lllll}
\hline & Compound 1 & Compound 2 & Compound 3 & Compound 4 \\
\hline Isomer A & $550,563,980$, & $552,618,980$, & $554,618,983$, & $542,620,980$, \\
& $996,1000,1613$ & $993,1000,1611$ & $995,1000,1612$ & $993,999,1612$ \\
Isomer B & $552,576,657$, & $555,580,635$, & $551,576,635$, & $556,583,635$, \\
& $635,1601,1602$ & $657,1598,1599$ & $651,1601,1599$ & $654,1599,1601$ \\
Isomer C & $715,981,995$, & $721,976,989$, & $705,977,996$, & $720,976,995$, \\
& $990,1614,1621$ & $995,1616,1622$ & 1615,1621 & 1615,1621 \\
Isomer D & $555,607,971$, & $552,610,970$, & $557,607,971$, & $533,640,966$, \\
& $999,1607,1622$ & $987,996,1606$, & $997,998,1607$, & $970,1604,1618$ \\
Experimental & $555,580,655$, & $554,583,650$, & $550,581,649$, & $561,580,651$, \\
data & 631,1603 & 1603 & 1607 & 1605 \\
\hline
\end{tabular}

\section{${ }^{1}$ H NMR spectra}

The proton magnetic resonance spectral data of ligand and its silicon complexes have been recorded in $\mathrm{CDCl}_{3}$. The ${ }^{1} \mathrm{H} \mathrm{NMR}$ spectrum of ligand showed a signal at $\delta 9.81 \mathrm{ppm}$ due to $\mathrm{NH}$ proton and a signal at $\delta 13.27 \mathrm{ppm}$ due to $\mathrm{OH}$ proton, both of which disappeared in silicon complexes showing involvement of both the groups in bonding. However, disappearance of these signals in complexes indicates the covalent bond formation between silicon and oxygen/ nitrogen due to deprotonation. The multiplets observed in the region of $\mathrm{N}-\mathrm{CH}_{2}$ and $=\mathrm{N}-\mathrm{CH}_{2}$ signals indicates chemically non-equivalent ethylene protons.

\section{${ }^{13}$ C NMR spectra}

The ${ }^{13} \mathrm{C}$ NMR spectral data for ligand and its metal complexes in $\mathrm{CDCl}_{3}$ supports coordination of ligand through azomethine nitrogen. Shifts in the positions of carbon atoms adjacent to atoms involved in complex formation indicate bonding pattern in the complexes. Downfield shift of ${ }^{13} \mathrm{C}$ signals due to $\mathrm{C}$ atoms attached to azomethine nitrogen further supports the involvement of azomethine group in complexation.

\section{${ }^{29}$ Si NMR spectra}

In order to confirm the coordination in complexes, ${ }^{29} \mathrm{Si} \mathrm{NMR}$ spectra were recorded in $\mathrm{CDCl}_{3}$. Sharp signals at $\delta-145.5,-155.1,-145.7$ and -153.9 ppm were assigned to $\mathbf{1}, \mathbf{2}, \mathbf{3}$ and 4 complexes, respectively. The values were compared with ${ }^{29} \mathrm{Si}$ NMR shifts obtained theoretically on the basis of DFT (B3LYP) with $3-21+\mathrm{G}^{*}$ basis set which also indicates formation of hexacoordinated silicon complex. 


\section{Conclusions}

On the basis of results discussed so far, spectral data and theoretical studies suggested a suitable hexa-coordination for the prepared silicon complexes. In the present work, we have calculated theoretically ${ }^{29} \mathrm{Si}$ NMR shifts and IR frequencies which evidenced the formation of hexacoordinate silicon complexes. In addition, the molecular geometries of prepared complexes were investigated by using semi-empirical studies. The calculations were performed on the basis of AM1, PM3, PM3MM and MNDO methods. The prepared complexes were also characterized by elemental analysis, IR and NMR spectroscopy. Their computational studies enabled verification of coordination in synthesized complexes.

\section{Experimental Section}

General Procedures. All the reactions were performed under dry nitrogen atmosphere using glass vacuum line. Solvents were dried and purified according to standard procedures reported in literature ${ }^{22}$ and stored under nitrogen. Salicyaldehyde (CDH, India) was purified by distillation under reduced pressure. Diethylenetriamine commercially available with Loba Chemicals, India was used as such. Methyltrichlorosilane, ethyltrichlorosilane, phenyltrichlorosilane and vinyltrichlorosilane were purchased from Aldrich, India. Infrared spectra were routinely obtained as nujol mulls on a Perkin Elmer RX-I FT IR Spectrophotometer. The ${ }^{1} \mathrm{H},{ }^{13} \mathrm{C}$ and ${ }^{29} \mathrm{Si}$ NMR spectra were recorded on Jeol FT NMR (AL $300 \mathrm{M} \mathrm{Hz}$ ) spectrometer with TMS as the internal standard. C H N analyses of samples were performed on a Perkin Elmer model $2400 \mathrm{C} \mathrm{H} \mathrm{N}$ analyzer while Si contents were estimated gravimetrically.

The quantum mechanical calculations were carried out using the GAUSSIAN 03 series of programs. The IR frequencies and ${ }^{29} \mathrm{Si}$ NMR shifts were calculated at PM3 and Density Functional Theory level (DFT), using Becke's three parameter hybrid exchange functional and the correlation functional of Lee, Yang, and Parr (B3LYP) with 3-21+G* basis set. Geometries were fully optimized by using semi-empirical methods.

\section{$N, N$ '-Diethylenetriamine-bis(salicylideneimine)}

The ligand was synthesized using a method reported in the literature ${ }^{2}$. To an ethanolic solution of salicylaldehyde was added an ethanolic solution of diethylenetriamine and the contents therein were refluxed for $4 \mathrm{hrs}$. The resulting solution was cooled to room temperature. The solvent was removed under vacuum and orange-yellow oil thus obtained was finally washed with hexane and dried under vacuum. The product was obtained as yellow oil; Yield: $70 \%$, IR (Nujol/ $\left.\mathrm{KBr} \mathrm{cm}^{-1}\right)$ : $1631 \mathrm{sh}(v \mathrm{C}=\mathrm{N}), 3410-3050 \mathrm{~b}(v \mathrm{O}-\mathrm{H}$ and $v \mathrm{~N}-\mathrm{H}) ;{ }^{1} \mathrm{H}$ NMR $\left(\mathrm{CDCl}_{3}, \mathrm{ppm}\right): \delta 2.83\left(\mathrm{t}, \mathrm{NCH}_{2}\right)$, $3.54\left(\mathrm{t},=\mathrm{NCH}_{2}\right), 8.28(\mathrm{~s}, \mathrm{~N}=\mathrm{CH}), 6.77-7.48\left(\mathrm{~m}\right.$, aromatic), $13.27(\mathrm{~s}, \mathrm{O}-\mathrm{H}), 9.81(\mathrm{~s}, \mathrm{~N}-\mathrm{H}) ;{ }^{13} \mathrm{C}$ $\operatorname{NMR}\left(\mathrm{CDCl}_{3}, \mathrm{ppm}\right): \delta 47.61\left(\mathrm{NCH}_{2}\right), 55.46\left(=\mathrm{NCH}_{2}\right), 164.01(\mathrm{~N}=\mathrm{CH}), 114-159$ (aromatic). 


\section{Complex 1}

In $25 \mathrm{~mL}$ THF, ligand $(2.6 \mathrm{~g}, 8.5 \mathrm{mmol})$ and triethylamine $(3.5 \mathrm{~mL}, 25.5 \mathrm{mmol})$ were stirred at room temperature and methyltrichlorosilane $(1.27 \mathrm{~g}, 8.5 \mathrm{mmol})$ was added dropwise. The contents were stirred for $3 \mathrm{hrs}$ at room temperature. The mixture was allowed to stand overnight in refrigerator, and then precipitated triethylamine hydrochloride was filtered off and washed with $10 \mathrm{~mL}$ THF three times. The solvent was removed from filtrate under vacuum and yellow solid was isolated from hexane $(25 \mathrm{~mL})$; Yield: $67 \%$. Anal. Calcd for $\mathrm{C}_{19} \mathrm{H}_{21} \mathrm{~N}_{3} \mathrm{O}_{2} \mathrm{Si}$ : C, 64.93; H, 6.02; N, 11.96; Si, 7.99; Found: C, 64.87; H, 6.07; N, 11.93; Si, 8.09; ${ }^{1} \mathrm{H}$ NMR $\left(\mathrm{CDCl}_{3}, 300\right.$ $\mathrm{MHz}) ; \delta$ 2.80-2.92 (m, N-CH$) ; 3.27-3.38\left(\mathrm{~m},=\mathrm{N}-\mathrm{CH}_{2}\right) ; 8.34(\mathrm{~s}, \mathrm{~N}=\mathrm{CH}) ; 6.67-7.64(\mathrm{~m}$, Aromatic region); $0.09\left(\mathrm{~s}, \mathrm{CH}_{3}\right) ;{ }^{13} \mathrm{C} \mathrm{NMR}\left(\mathrm{CDCl}_{3}, 75 \mathrm{MHz}\right) ; \delta 47.36\left(\mathrm{~N}-\mathrm{CH}_{2}\right) ; 55.27\left(=\mathrm{N}-\mathrm{CH}_{2}\right)$; $163.62(\mathrm{~N}=\mathrm{CH}) ; 114-158$ (Aromatic region); $23.51\left(\mathrm{Si}_{-} \mathrm{CH}_{3}\right) ;{ }^{29} \mathrm{Si} \mathrm{NMR}\left(\mathrm{CDCl}_{3}, 59.595 \mathrm{MHz}\right) ; \delta$ Theor./Exp.; -147.2/-145.5.

\section{Complex 2}

To a stirred solution of ligand $(1.94 \mathrm{~g}, 6.24 \mathrm{mmol})$ and triethylamine $(2.6 \mathrm{~mL}, 18.72 \mathrm{mmol})$ in THF (25 mL), phenyltrichlorosilane (1.32 g, $6.24 \mathrm{mmol})$ was added dropwise. The contents were allowed to stir at $35^{\circ} \mathrm{C}$ for $2 \mathrm{hrs}$. The obtained solid was filtered and washed with $15 \mathrm{~mL}$ of THF. The volatiles were removed under reduced pressure and light yellow solid was obtained from hexane (25 mL). Yield: $72 \%$. Anal. Calcd for $\mathrm{C}_{24} \mathrm{H}_{23} \mathrm{~N}_{3} \mathrm{O}_{2} \mathrm{Si}: \mathrm{C}, 69.70 ; \mathrm{H}, 5.61 ; \mathrm{N}, 10.16$; Si, 6.79; Found: C, 69.99; H, 5.56; N, 10.01; Si, 6.71; ${ }^{1} \mathrm{H}$ NMR $\left(\mathrm{CDCl}_{3}, 300 \mathrm{MHz}\right) ; \delta 2.75-2.89$ (m, $\left.\mathrm{N}-\mathrm{CH}_{2}\right) ; 3.25-3.37\left(\mathrm{~m},=\mathrm{N}-\mathrm{CH}_{2}\right) ; 8.29(\mathrm{~s}, \mathrm{~N}=\mathrm{CH}) ; 6.90-7.73(\mathrm{~m}$, Aromatic region); 6.90-7.73 (m, $\left.\mathrm{C}_{6} \mathrm{H}_{5}\right) ;{ }^{13} \mathrm{C} \mathrm{NMR}\left(\mathrm{CDCl}_{3}, 75 \mathrm{MHz}\right) ; \delta 43.90\left(\mathrm{~N}-\mathrm{CH}_{2}\right) ; 53.10\left(=\mathrm{N}-\mathbf{C H}_{2}\right) ; 160.61(\mathrm{~N}=\mathbf{C H}) ; 114-$ 158 (Aromatic region); 126-128 $\left(\mathrm{Si}_{-} \mathrm{C}_{6} \mathrm{H}_{5}\right) ;{ }^{29} \mathrm{Si} \mathrm{NMR}\left(\mathrm{CDCl}_{3}, 59.595 \mathrm{MHz}\right) ; \delta$ Theor./Exp.; $148.5 /-155.1$.

\section{Complex 3}

In this method, ligand $(2.28 \mathrm{~g}, 7.3 \mathrm{mmol})$ and triethylamine $(3.0 \mathrm{~mL}, 21.9 \mathrm{mmol})$ were mixed in $25 \mathrm{~mL}$ THF and then, and ethyltrichlorosilane $(1.20 \mathrm{~g}, 7.3 \mathrm{mmol})$ was added dropwise with constant stirring. Rest of the procedure is analogous to method given for complex 1. Yield: $65 \%$. Anal. Calcd for $\mathrm{C}_{20} \mathrm{H}_{23} \mathrm{~N}_{3} \mathrm{O}_{2} \mathrm{Si}$ : C, 65.72; H, 6.34; N, 11.50; Si, 7.68; Found: C, 65.82; H, 6.35; $\mathrm{N}, 11.63$; $\mathrm{Si}, 7.76 ;{ }^{1} \mathrm{H}$ NMR $\left(\mathrm{CDCl}_{3}, 300 \mathrm{MHz}\right) ; \delta 2.81-2.90\left(\mathrm{~m}, \mathrm{~N}-\mathrm{CH}_{2}\right) ; 3.28-3.39(\mathrm{~m},=\mathrm{N}-$ $\left.\mathrm{CH}_{2}\right) ; 8.32(\mathrm{~s}, \mathrm{~N}=\mathrm{CH}) ; 6.75-7.44\left(\mathrm{~m}\right.$, Aromatic region); $1.4\left(\mathrm{t}, \mathrm{CH}_{3}\right) ;{ }^{13} \mathrm{C} \mathrm{NMR}\left(\mathrm{CDCl}_{3}, 75\right.$ $\mathrm{MHz}) ; \delta 46.08\left(\mathrm{~N}-\mathrm{CH}_{2}\right) ; 54.39\left(=\mathrm{N}-\mathrm{CH}_{2}\right) ; 163.98(\mathrm{~N}=\mathrm{CH}) ; 115-159$ (Aromatic region); 33.0 $\left(\mathrm{Si}-\mathrm{CH}_{2}\right) ;-15\left(\mathrm{CH}_{2}-\mathrm{CH}_{3}\right) ;{ }^{29} \mathrm{Si} \mathrm{NMR}\left(\mathrm{CDCl}_{3}, 59.595 \mathrm{MHz}\right) ; \delta$ Theor./Exp.; -146.5/-145.7.

\section{Complex 4}

Ligand $(2.6 \mathrm{~g}, 8.5 \mathrm{mmol})$ was dissolved in THF $(25 \mathrm{~mL})$ and triethylamine $(3.5 \mathrm{~mL}, 25.5 \mathrm{mmol})$ was added dropwise. The solution was stirred at room temperature and vinyltrichlorosilane (1.27 $\mathrm{g}, 8.5 \mathrm{mmol}$ ) was added dropwise. After one day, precipitated salt was filtered and filtrate was evaporated under vacuum. The yellow solid was washed with hexane and dried under vacuum. 
Yield: $61 \%$. Anal. Calcd for $\mathrm{C}_{20} \mathrm{H}_{21} \mathrm{~N}_{3} \mathrm{O}_{2} \mathrm{Si}$ : C, 66.09; H, 5.82; N, 11.56; Si, 7.01; Found: C, 65.99; H, 5.89; N, 11.63; Si, 7.03. ${ }^{1} \mathrm{H} \mathrm{NMR}\left(\mathrm{CDCl}_{3}, 300 \mathrm{MHz}\right) ; \delta 2.77-2.88\left(\mathrm{~m}, \mathrm{~N}-\mathrm{CH}_{2}\right) ; 3.26-$ $3.35\left(\mathrm{~m},=\mathrm{N}-\mathrm{CH}_{2}\right) ; 8.30(\mathrm{~s}, \mathrm{~N}=\mathrm{CH}) ; 6.70-7.15\left(\mathrm{~m}\right.$, Aromatic region); $4.8(\mathrm{t}, \mathrm{CH}) ; 5.1\left(\mathrm{~d}, \mathrm{CH}_{2}\right)$;

${ }^{13} \mathrm{C} \mathrm{NMR}\left(\mathrm{CDCl}_{3}, 75 \mathrm{MHz}\right) ; \delta 43.85\left(\mathrm{~N}-\mathrm{CH}_{2}\right) ; 53.09\left(=\mathrm{N}-\mathrm{CH}_{2}\right) ; 161.23(\mathrm{~N}=\mathbf{C H}) ; 115-159$ (Aromatic region); 121-123 $\left(\mathrm{Si}-\mathbf{C H}=\mathrm{CH}_{2}\right) ;{ }^{29} \mathrm{Si} \mathrm{NMR}\left(\mathrm{CDCl}_{3}, 59.595 \mathrm{MHz}\right) ; \delta$ Theor./Exp.; 145.4/-153.9.

\section{Acknowledgements}

The authors are thankful to UGC, New Delhi for providing financial support.

\section{References}

1. Emara, A. A.; Ali, A. M.; Ragab, E. M.; El-Asmy, A. A. J. Coord. Chem. 2008, 61, 2968.

2. Benabdallah, T.; Al-Taiar, A. H.; Reffas, H. S. Afr. J. Chem. 2004, 57, 33.

3. Voronkov, M. G.; Dyakov, V. M.; Kirpichenko, S. V. J. Organomet. Chem. 1982, 233, 1.

4. Tandura, S. N.; Voronkov, M. G.; Alekseev, N. V. Top. Curr. Chem. 1986, 131, 99.

5. Corriu, R. J. P.; Reye, C.; Claude, C.; Young, J. C. Chem. Rev. 1993, 93, 1371.

6. Lippe, K.; Gerlach, D.; Kroke, E.; Wagler, J. Organometallics. 2009, 28, 621.

7. Wagler, J. Organometallics. 2007, 26, 155.

8. Wagler, J.; Gerlach, D.; Roewer, G. Inorg. Chim. Acta 2007, 360, 1935.

9. Wagler, J.; Roewer, G. Inorg. Chim. Acta 2007, 360, 1717.

10. Wagler, J.; Brendler, E. Z. Naturforsch. 2007, 62b, 225.

11. Bohme, U.; Haushalter, J. Inorg. Chem. Comm. 2009, 12, 35.

12. Belwal, S.; Fahmi, N.; Singh, R. V. Appl. Organomet. Chem. 2008, 22, 615.

13. Maanju, S.; Chaudhary, A.; Singh, R. V. Main Group Met. Chem. 2006, 29, 31.

14. Jain, M.; Singh, R. V.; Bioinorg. Chem. Appl. 2006, $1,1$.

15. Singh, R. V.; Jain, M.; Deshmukh, C. N. Appl. Organomet. Chem. 2005, 19, 879.

16. Puri, J. K.; Singh, G.; Duggal, P.; Phosphorus, Sulfur, Silicon Relat. Elem. 2008, 183, 1853.

17. Puri, J. K.; Singh, G.; Duggal, P. Main Group Met. Chem., 2007, 30, 31.

18. Narula, S. P.; Puri, M.; Garg, N.; Puri, J. K.; Chadha, R. K. Phosphorus, Sulfur, Silicon Relat. Elem. 2007, 182, 569.

19. Belyaeva, V. V.; Frolov, Y. L.; Voronkov, M. G. ARKIVOC 2005, (vii), 67.

20. Wagler, J.; Schley, M.; Gerlach, D.; Bohme, U.; Brendler, B.; Roewer, G. Z. Naturforsch., 2005, 60b, 1054.

21. Kim, D. H.; Lee, M. J.; Oh, S. W., Bull. Korean Chem. Soc. 1998, 19, 847.

22. Riddickk, J. A.; Bunger, W. B.; Sakano, T. K. Techniques of Chemistry, Organic Solvent, $4^{\text {th }}$ Edn.; Wiley Interscience: New York, 1989. 